\title{
Heterogeneous Gene Expression and Functional Activity of Ryanodine Receptors in Resistance and Conduit Pulmonary as well as Mesenteric Artery Smooth Muscle Cells
}

\author{
Yun-Min Zheng Qing-Song Wang Qing-Hua Liu Rakesh Rathore \\ Vishal Yadav Yong-Xiao Wang \\ Center for Cardiovascular Sciences, Albany Medical College, Albany, N.Y., USA
}

\section{Key Words}

Ryanodine receptor $\cdot$ Calcium release $\cdot$ Hypoxia $\cdot$

Pulmonary artery $\cdot$ Mesenteric artery

\begin{abstract}
Background: Hypoxia causes heterogeneous contractile responses in resistance and conduit pulmonary as well as systemic (mesenteric) artery smooth muscle cells (RPASMCs, CPASMCs and MASMCs), but the underlying mechanisms are largely unknown. In this study, we aimed to investigate whether the gene expression and functional activity of ryanodine receptors (RyRs) would be different in these 3 cell types. Methods: RyR mRNA expression, $\mathrm{Ca}^{2+}$ sparks and $\left[\mathrm{Ca}^{2+}\right]_{i}$ were measured by real-time quantitative RT-PCR, laser scanning confocal microscopy and wide-field fluorescence microscopy, respectively. Results: All 3 RyR subtype (RyR1, RyR2 and RyR3) mRNAs are expressed in RPASMCs, CPASMCs and MASMCs, but their expression levels are different. Spontaneous $\mathrm{Ca}^{2+}$ sparks (functional events of RyRs) show distinct frequency, amplitude, duration, size and kinetics in these 3 cell types. Similarly, activation of RyRs by caffeine, 4-chloro$\mathrm{m}$-cresol or high $\mathrm{K}^{+}$induces differential $\mathrm{Ca}^{2+}$ release. Moreover, hypoxia-induced increase in $\left[\mathrm{Ca}^{2+}\right]_{i}$ is largest in MASMCs relative to CPSAMCs and smallest in RPASMCs. Conclusion: This study provides comprehensive evidence that RyRs are heterogeneous in gene expression and functional activity in
\end{abstract}

\begin{tabular}{ll}
\hline KARGER & $\oplus$ 2008 S. Karger AG, Basel \\
$\begin{array}{l}\text { Fax }+41613061234 \\
\begin{array}{l}\text { E-Mail karger@karger.ch } \\
\text { www.karger.com }\end{array}\end{array}$ & $\begin{array}{l}\text { Accessible online at: } \\
\text { www.karger.com/jvr }\end{array}$
\end{tabular}

RPASMCs, CPASMCs and MASMCs, which may contribute to the diversity of excitation-contraction coupling and hypoxic $\mathrm{Ca}^{2+}$ responses in different vascular smooth muscle cells.

Copyright $\odot 2008$ S. Karger AG, Basel

\section{Introduction}

It is well known that hypoxia results in vasoconstriction in pulmonary arteries (hypoxic pulmonary vasoconstriction, HPV). This vasoconstriction can increase vascular resistance in poorly ventilated regions of the lung to ensure that blood flow is routed to well-aerated areas, which preserves the sufficient matching of regional alveolar ventilation and pulmonary perfusion, thereby allowing adequate gas exchange between the airways and pulmonary arteries to supply oxygenated blood to the rest of the body. During hypoxic stimulation, however, systemic arteries often dilate, which leads to a fall in arterial blood pressure to increase vascular conductance; thus, blood flow remains more or less constant locally in organs or tissues. Furthermore, hypoxic vasoconstriction is much greater in resistance than conduit pulmonary arteries [1-4]. An increase in intracellular $\mathrm{Ca}^{2+}$ concentration, $\left[\mathrm{Ca}^{2+}\right]_{i}$, in pulmonary artery smooth muscle cells (PASMCs) is a key element for HPV. We have recently found that hypoxia induces a large increase in $\left[\mathrm{Ca}^{2+}\right]_{i}$ and

Dr. Yong-Xiao Wang

Albany Medical College, Center for Cardiovascular Sciences

47 New Scotland Avenue

Albany, NY 12158 (USA)

Tel. +1 518262 9506, Fax +1 518262 8101, E-Mail wangy@mail.amc.edu 
contraction in PASMCs, but not in mesenteric artery smooth muscle cells (MASMCs) [5, 6]. Similarly, Vadula et al. [7] have reported that hypoxia significantly increases $\left[\mathrm{Ca}^{2+}\right]_{\mathrm{i}}$ in PASMCs, but not in cerebral artery smooth muscle cells (SMCs). However, little is known about the cellular and molecular mechanisms for the heterogeneity of hypoxic responses in resistance and conduit PASMCs (RPASMCs and CPASMCs) as well as systemic (mesenteric) artery myocytes.

Using pharmacological blockers and gene deletion mice, we and other investigators have demonstrated that ryanodine receptor $(\mathrm{RyR}) \mathrm{Ca}^{2+}$ release channels play an important role in hypoxic increases in $\left[\mathrm{Ca}^{2+}\right]_{\mathrm{i}}$ and the subsequent contraction in RPASMCs [5, 7-12]. Three RyRs (RyR1, RyR2 and RyR3) are expressed in mammalian cells, each encoded by a distinct gene. Our recent study has revealed that RyR1, RyR2 and RyR3 mRNAs are expressed in freshly isolated rat RPASMCs [12]. In support of our findings, all $3 \mathrm{RyR}$ mRNAs are detected in rat intralobar pulmonary artery tissues [13]. Different studies using systemic vascular tissues or cultured cells indicate RyR1, RyR2 and RyR3 mRNA expression [1416], abundant RyR3, little RyR2 and no RyR1 mRNA expression [17, 18], and only RyR1 mRNA expression [18]. Nevertheless, there is no study to examine and compare the expression of RyR1, RyR2 and RyR3 in RPASMCs, CPASMCs and MASMCs.

Native RyR1 in skeletal muscle cells is physically coupled to plasmalemmal voltage-dependent $\mathrm{Ca}^{2+}$ channels (VDCCs), by which a membrane depolarization causes a conformational change in VDCCs and then activates RyR1 without requiring $\mathrm{Ca}^{2+}$ influx, leading to massive $\mathrm{Ca}^{2+}$ release. In cardiac cells, RyR2 is tightly, but not physically linked to VDCCs; as a result, $\mathrm{Ca}^{2+}$ influx through VDCCs causes RyR2 activation and then further $\mathrm{Ca}^{2+}$ release, a process called $\mathrm{Ca}^{2+}$-induced $\mathrm{Ca}^{2+}$ release (CICR). RyR3 may not functionally couple to VDCCs in skeletal muscle cells, but it displays the activity of CICR when expressed in cell lines [19]. In addition, $\mathrm{Ca}^{2+}$ sensitivity is significantly lower in skeletal RyR1 than cardiac RyR2 and skeletal RyR3 [19]. Three RyRs can be diversely regulated by redox agents. It has been reported that NADH activates skeletal RyR1, but inhibits cardiac RyR2 [20]. Moreover, RyR3 shows a lower affinity but higher response to calmodulin than RyR1 in the presence of redox agents [21]. Thus, RyR1, RyR2 and RyR3 may form a distinct $\mathrm{Ca}^{2+}$ release unit with plasmalemmal VDCCs and show a different sensitivity to $\mathrm{Ca}^{2+}$ and redox agents.

Hypoxia inhibits voltage-dependent $\mathrm{K}^{+}\left(\mathrm{K}_{\mathrm{V}}\right)$ channels and subsequently causes membrane depolarization in
PASMCs [22, 23], which may perhaps result in VDCC opening and $\mathrm{Ca}^{2+}$ influx, thereby leading to RyR activation and further $\mathrm{Ca}^{2+}$ release. There is also evidence that different hypoxic responses in PASMCs and systemic artery SMCs are related to the intracellular generation of reactive oxygen species $[6,24,25]$. These results, together with the above-mentioned, distinct characteristics of 3 RyRs in response to $\mathrm{Ca}^{2+}$ influx and redox agents, led us to hypothesize that the gene expression and functional activity of RyRs may be heterogeneous in RPASMCs, CPASMCs and systemic artery SMCs. As an initial step to test this intriguing hypothesis, we sought to examine and compare the expression levels of RyR1, RyR2 and RyR3 mRNAs in RPASMCs, CPASMCs and MASMCs, using real-time quantitative RT-PCR. In this set of experiments, freshly isolated cells were utilized to minimize the potential problems with contamination of endothelial and other cells in vascular tissues [26] or changes in gene expression in cultured cells $[18,27,28]$. In order to provide functional evidence for the heterogeneity of RyR expression, we next examined whether spontaneous $\mathrm{Ca}^{2+}$ sparks (functional events of RyRs) as well as RyR agonist- and hypoxia-induced $\mathrm{Ca}^{2+}$ release were different in these 3 types of vascular SMCs using a laser scanning confocal and wide-field fluorescence microscope.

\section{Methods}

\section{Cell Preparation}

Freshly isolated vascular SMCs were obtained from resistance (third-order and smaller branches) and conduit (main trunk) pulmonary as well as resistance mesenteric arteries of adult male Swiss Webster mice (Taconic, Germantown, N.Y., USA), as described previously [12]. Briefly, animals were euthanized with intraperitoneal injections of sodium pentobarbital $(150 \mathrm{mg} / \mathrm{kg})$ as approved by the Institutional Animal Use and Care Committee of Albany Medical College. Resistance and conduit pulmonary as well as mesenteric arteries were removed and cleaned of the connective tissue and endothelium in normal physiological saline solution (PSS), and then cut into small pieces. The small arteries were incubated in low $\mathrm{Ca}^{2+}(0.1 \mathrm{mM})$ PSS $\left(37^{\circ} \mathrm{C}\right)$ containing (in $\mathrm{mg} / \mathrm{ml}) 1.5$ papain, 0.25 dithioerythritol and 1 bovine serum albumin (BSA) for $20 \mathrm{~min}$, and subsequently digested in low $\mathrm{Ca}^{2+}$ PSS containing (in $\mathrm{mg} / \mathrm{ml}$ ) 1 type II collagenase, 1 type $\mathrm{H}$ collagenase, 1 dithiothreitol and 1 BSA for 10-15 min. Single cells were harvested by gentle trituration and kept on ice for use up to approximately 6 h. Normal PSS contained (in $\mathrm{mM}$ ): $\mathrm{NaCl} 130, \mathrm{KCl}$ 5.4, $\mathrm{CaCl}_{2} 1.8, \mathrm{MgSO}_{4} 1$, HEPES 10 and glucose $10(\mathrm{pH} 7.4)$.

\section{Immunofluorescence Staining}

Expression of smooth muscle-specific actin and myosin in freshly isolated cells from resistance and conduit pulmonary as well as mesenteric arteries were examined using immunofluores- 
cence staining, as described previously [12]. Briefly, cells were placed on fibronetin-coated glass coverslips for approximately 30 min at room temperature to allow the cells to well attach to the coverslips. Subsequently, cells were fixed in $4 \%$ paraformaldehyde for 15 min, permeabilized with $0.2 \%$ Triton X-100 in PSS for 30 min, and then incubated with anti-actin (smooth muscle) or antimyosin (smooth) antibody (Sigma, St. Louis, Mo., USA) at $4^{\circ} \mathrm{C}$ overnight, followed with Alexa Fluor 488-conjugated anti-mouse antibody (according to the host species of primary antibody, 1:500 dilution) for $2 \mathrm{~h}$. Immunofluorescence staining was examined using a Leica LSP2 laser scanning confocal microscope equipped with a $40 \times$ oil immersion objective (numerical aperture 1.25). Alexa Fluor 488 was excited at 488 using a krypton-argon laser, and the emitted fluorescence at $510 \mathrm{~nm}$ was detected. Simultaneous examination of fluorescence images of smooth muscle-specific actin staining and transmitted light images of the same cells were performed using a Zeiss LSM510 laser scanning confocal microscope with a $40 \times$ oil immersion objective (numerical aperture 1.3). The argon laser at $488 \mathrm{~nm}$ was used for excitation, and the emitted fluorescence at $510 \mathrm{~nm}$ as well as transmitted light were detected by separate high-sensitivity photomultiplier tubes via fluorescent and transmitted light detectors, respectively.

\section{Real-Time Quantitative RT-PCR}

The experimental protocol was similar to that described previously [12]. Total RNAs were obtained from freshly isolated mouse vascular SMCs. Individual cells were collected using a patch clamp manipulator. In each single RT-PCR experiment, approximately 200 RPASMCs, CPASMCs and MASMCs collected from an individual mouse were used. The experiment was repeated 6 times. cDNAs were synthesized, and then amplified by specific target gene forward and reverse primers with the iQ SYBR Green Supermix using an iCycler iQ Real-Time PCR Detection System (Bio-Rad, Hercules, Calif., USA). The forward and reverse primers were: 5'-CCGGCGATGAATATGAACTT-3' and 5'-TGATAGCCAGCAGAATGACG-3' for RyR1 gene; 5'-CATGGACAGCTTCCCCTGAA-3' and 5'-GTGTGACTGCCGTGCTTGG-3' for RyR2 gene; $5^{\prime}$-CTGGCCATCATTCAAGGTCT-3' and $5^{\prime}$-GTCTCCATGTCTTCCCGTA-3' for RyR3 gene. The housekeeping gene glyceraldehyde-3-phosphate dehydrogenase $(\mathrm{GAPDH})$ was used as endogenous control. To quantify mRNA levels, the cloned DNAs for RyR1, RyR2, RyR3 and GAPDH genes were used for constructing standard curves, which were made by plotting the cycle threshold versus the log of known concentrations. The cloned DNAs were sequenced for verification. Known standard DNAs and unknown sample cDNAs at series dilutions (1:10) were simultaneously amplified. No reverse transcriptase and no template control experiments were performed to validate the product specificity. The amplification products were checked by electrophoresis. The mRNA levels of RyR subtypes were normalized to the level of GAPDH.

\section{Measurement of $\mathrm{Ca}^{2+}$ Sparks}

$\mathrm{Ca}^{2+}$ sparks were measured using a laser scanning confocal microscope (Zeiss LSM510; Zeiss, Göttingen, Germany), as reported previously [29]. Cells were loaded with fluo-4/AM (2.5 $\mu \mathrm{M}$ ) for $25 \mathrm{~min}$ at room temperature (approx. $22^{\circ} \mathrm{C}$ ), and then perfused with bath solution for $10 \mathrm{~min}$ to wash out extracellular dye and to allow the further conversion of intracellular dye into its nonester form. The dye was excited with $488 \mathrm{~nm}$ light emitted from a krypton/argon laser. The emission fluorescence at $505 \mathrm{~nm}$ was detected. High-bandwidth temporal profiles of fluorescence intensity were obtained using the line-scanning mode. Each line image was taken every $1.9 \mathrm{~ms}$. The spatial resolutions for the $\mathrm{x}-\mathrm{y}$ axis and $\mathrm{z}$ axis were 0.9 and $1.5 \mu \mathrm{m}$, respectively. The spatiotemporal characteristics of $\mathrm{Ca}^{2+}$ sparks (for example, frequency, amplitude, duration and lateral size) were analyzed using the Interactive Data Language software (Research Systems, Boulder, Colo., USA) [29]. The $\mathrm{Ca}^{2+}$ spark amplitude was determined as the difference between the resting fluorescence $\left(\mathrm{F}_{0}\right)$ and maximal fluorescence of a spark, and expressed as $\Delta \mathrm{F} / \mathrm{F}_{0}\left(\mathrm{~F} / \mathrm{F}_{0}-1\right)$, where $\mathrm{F}$ was the fluorescence intensity of each confocal image; frequency was assessed as the number of $\mathrm{Ca}^{2+}$ sparks in each line scan image per second and per micrometer of the line length; rise time was designated as the duration between the onset and peak of a spark; full duration at half maximum was measured at the time when a spark reached half the way to its peak; decay time was determined as the duration between the peak and end of a spark; full width at half maximum was calculated as the width of the spark that exceeds half its amplitude; rise rate was defined as the average rate between the onset and peak of a spark; decay rate was determined by the average rate between the spark peak and end.

\section{Measurement of Whole-Cell $\left[\mathrm{Ca}^{2+}\right]_{i}$}

Measurements of $\left[\mathrm{Ca}^{2+}\right]_{i}$ were made using a wide-field fluorescence microscope (IonOptix Corp., Milton, Mass., USA) [12]. Vascular myocytes were loaded with fura-2/AM $(2.5 \mu \mathrm{M})$ for 25 min at room temperature and then perfused with dye-free bath solution for $10 \mathrm{~min}$. Fura-2 was alternatively excited at wavelengths of 340 and $380 \mathrm{~nm}$ to acquire an image pair in $0.1 \mathrm{~s}$ and the emitted fluorescence was detected at $510 \mathrm{~nm}$. $\left[\mathrm{Ca}^{2+}\right]_{\mathrm{i}}$ was calculated by the following equation:

$$
\left[\mathrm{Ca}^{2+}\right]_{\mathrm{i}}=\left(\mathrm{R}-\mathrm{R}_{\min }\right) /\left(\mathrm{R}_{\max }-\mathrm{R}\right) \times \beta \times \mathrm{K}_{\mathrm{D}}
$$

Values of $\mathrm{R}_{\max }$ (maximum 340/380), $\mathrm{R}_{\min }$ (minimum 340/380) and $\beta$ (ratio of 380 fluorescence at $\mathrm{Ca}^{2+}$-free and saturating $\mathrm{Ca}^{2+}$ concentrations) were determined using $10 \mu \mathrm{M}$ ionomycin and 10 $\mathrm{mM} \mathrm{Ca}^{2+}$ or $10 \mu \mathrm{M}$ ionomycin and $10 \mathrm{mM}$ EGTA for saturating and $\mathrm{Ca}^{2+}$-free conditions, respectively. $\mathrm{K}_{\mathrm{D}}$ (dissociation constant for $\mathrm{Ca}^{2+}$ binding to fura-2) of $386 \mathrm{nM}$ was used [11].

\section{Hypoxic Challenge}

Hypoxia was achieved by perfusing a bath solution equilibrated with $20 \% \mathrm{O}_{2}, 5 \% \mathrm{CO}_{2}$ and $75 \% \mathrm{~N}_{2}$ (normoxic solution) to a solution equilibrated with $1 \% \mathrm{O}_{2}, 5 \% \mathrm{CO}_{2}$ and balance with $\mathrm{N}_{2}$ (hypoxic solution), as described previously [12]. The oxygen tension of the solution was monitored by an oxygen electrode (OXEL-1; WPI, Sarasota, Fla., USA). To avoid atmospheric $\mathrm{O}_{2}$ reequilibration with the hypoxic bath solution, a glass coverslip was placed on top of a specifically designed recording chamber that allowed input and output of bath solution to be equal. The contact surface between the coverslip and the chamber was sealed with high-vacuum grease. Under these conditions, the bath $\mathrm{pO}_{2}$ in the normoxic and hypoxic solution was approximately 140 and 20 Torr, respectively.

\section{Chemicals}

Alexa Flour 488-conjugated goat anti-mouse antibody, fura2/AM and fluo-4/AM were purchased from Molecular Probes (Eugene, Oreg., USA); caffeine and 4-chloro-m-cresol (CMC) were obtained from Sigma. 
Statistical Analysis

All data were expressed as means \pm SE. Statistical significance of differences between observations was determined by one-way ANOVA. $\mathrm{p}<0.05$ was accepted as a statistically significant level.

\section{Results}

\section{Expression of RyR Subtypes}

The expression patterns and levels of RyR1, RyR2 and RyR3 in freshly isolated RPASMCs, CPASMCs as well as MASMCs were examined by using real-time quantitative RT-PCR. In order to verify that the freshly isolated cells from pulmonary and mesenteric arteries were SMCs, we examined the expression of the smooth muscle-specific actin and myosin in these cells using immunofluorescence staining. Similar to our previous findings in freshly isolated cells from rat and mouse resistant pulmonary arteries [12, 25], here we showed that the freshly isolated cells from mouse resistance and conduit pulmonary as well as mesenteric arteries were all stained by antibodies against smooth muscle-specific actin and myosin. To determine the percentage of smooth muscle marker-positive cells, we simultaneously examined fluorescence images of smooth muscle actin staining and transmitted light images of the same cells using a Zeiss LSM510 confocal microscope. As shown in figure 1a, nearly all isolated cells from resistance pulmonary arteries were actin positive. Quantification analysis from 10 independent experiments indicates that $99 \%$ cells were actin positive (415 of a total of 419 cells). A similar percentage of actinpositive cells was observed for the cells isolated from conduit pulmonary and mesenteric arteries. Therefore, the freshly isolated, fairly elongated cells from resistance and conduit pulmonary as well as mesenteric arteries were SMCs, and were used as mRNA sources to examine RyR mRNA expression. As shown in figure $1 \mathrm{~b}$, gel electrophoresis revealed that the PCR products for RyR $1, \mathrm{RyR} 2$ and RyR3 genes matched the predicted size of 81,77 and 83 bp, respectively, indicating that RyR1, RyR2 and RyR3 were all expressed in 3 types of vascular SMCs, however, their expression levels were different in RPASMCs, CPASMCs and MASMCs (fig. 1c). The expression levels of RyR1, RyR2 and RyR3 were similar in RPASMCs; RyR $1 \approx$ RyR $2>$ RyR3 in CPASMCs and MASMCs. Additionally, RyR1 expression level was similar in all 3 vascular SMCs, RyR2 level in RPASMCs was similar to that in CPASMCs, but lower than that in MASMCs, and RyR3 level in RPASMCs was higher than that in CPASMCs and MASMCs.

\section{Spontaneous $\mathrm{Ca}^{2+}$ Sparks}

Spontaneous $\mathrm{Ca}^{2+}$ sparks, as a measure of elementary and functional events of RyRs, have been observed in several types of vascular myocytes including PASMCs and MASMCs [5, 30-32]. Here we examined whether spontaneous $\mathrm{Ca}^{2+}$ sparks could be different in freshly isolated mouse RPASMCs, CPASMCs and MASMCs. As shown in figure $2 \mathrm{a}$, we were able to observe spontaneous $\mathrm{Ca}^{2+}$ sparks in all 3 types of cells. However, the spatiotemporal characteristics of $\mathrm{Ca}^{2+}$ sparks were different between RPASMCs, CPASMCs and MASMCs (fig. 2b). The mean frequency of $\mathrm{Ca}^{2+}$ sparks was RPASMCs $\approx$ CPASMCs $<$ MASMCs ( $\mathrm{p}<0.05)$; the mean amplitude was RPASMCs $\approx$ CPASMCs < MASMCs; the mean rise time was RPASMCs $\approx$ MASMCs $<$ CPASMCs; the mean duration (full duration at half maximum) was RPASMCs < CPASMCs $\approx$ MASMCs; the mean decay time was RPASMCs $\approx$ CPASMCs < MASMCs; the mean spread size (full width at half maximum) was RPASMCs < CPASMCs $<$ CPASMCs. $\mathrm{A} \mathrm{Ca}^{2+}$ spark represents an elementary $\mathrm{Ca}^{2+}$ release event resulting from the opening of a cluster of several RyRs; as such, the rise rate is predominantly determined by the activation characteristics of RyRs. Considering this, we also analyzed $\mathrm{Ca}^{2+}$ spark rise and decay rates, and found that the average rise rate of $\mathrm{Ca}^{2+}$ sparks was CPASMCs $<$ RPASMCs < MASMCs, while the average decay rate was CPASMCs $<$ RPASMCs $\approx$ MASMCs.

\section{Caffeine-Induced $\mathrm{Ca}^{2+}$ Release}

To further provide functional evidence for the differential expression of RyRs in pulmonary and systemic artery SMCs, we investigated whether caffeine (a classic RyR agonist) could induce differential $\mathrm{Ca}^{2+}$ release behaviors in freshly isolated mouse RPASMCs, CPASMCs and MASMCs. Application of caffeine ( $3 \mathrm{mM})$ induced a small increase in $\left[\mathrm{Ca}^{2+}\right]_{\mathrm{i}}\left(\mathrm{Ca}^{2+}\right.$ release $)$ in an RPASMC, a moderate increase in $\left[\mathrm{Ca}^{2+}\right]_{\mathrm{i}}$ in a CPASMC and a large increase in $\left[\mathrm{Ca}^{2+}\right]_{\mathrm{i}}$ in an MASMC. The mean increases in $\left[\mathrm{Ca}^{2+}\right]_{\mathrm{i}}$ were $235 \pm 62 \mathrm{nM}$ in RPASMCs $(\mathrm{n}=13), 478 \pm$ $52 \mathrm{nM}$ in CPASMCs $(\mathrm{n}=14)$ and $760 \pm 101 \mathrm{nM}$ in MASMCs $(n=8)$. At a higher concentration $(30 \mathrm{mM})$, caffeine induced a similar $\mathrm{Ca}^{2+}$ release in RPASMCs and CPASMCs, but a larger $\mathrm{Ca}^{2+}$ release in MASMCs (fig. 3).

\section{CMC-Induced $\mathrm{Ca}^{2+}$ Release}

Similar to caffeine, the RyR agonist CMC also evoked divergent $\mathrm{Ca}^{2+}$ release in RPASMCs, CPASMCs and MASMCs. CMC $(0.3 \mathrm{mM})$ induced a larger increase in $\left[\mathrm{Ca}^{2+}\right]_{\mathrm{i}}$ in RPASMCs and CPASMCs than in MASMCs. 
Fig. 1. RyR subtypes are heterogeneously expressed in freshly isolated mouse RPASMCs, CPASMCs and MASMCs. a Expression of the smooth muscle-specific actin was found in nearly all isolated cells from resistance pulmonary arteries. Fluorescence image for actin staining (left) and transmitted light image (right) were simultaneously taken using a Zeiss LSM510 laser scanning confocal microscope. Cells were incubated with a primary antibody for smooth muscle-specific actin and then stained with Alexa Flour 488-conjugated anti-mouse antibody. b Gel electrophoresis reveals expression of RyR1, RyR2 and RyR3 mRNAs in RPASMCs, CPASMCs and MASMCs. The predicted PCR product sizes for RyR1, RyR2, RyR3 and GAPDH were 81, 77, 83 and 122 bp, respectively. c Graphs show the relative mRNA expression levels of RyR1, RyR2 and RyR3 in RPASMCs, CPASMCs and MASMCs. The relative mRNA expression levels were obtained by normalizing the absolute expression levels of RyR1, RyR2 and RyR3 to that of GAPDH. Data were obtained from 6 separate experiments. ${ }^{*} \mathrm{p}<0.05$ compared with RyR1 in the same type of vascular SMCs; ${ }^{+} \mathrm{p}<0.05$ compared with RyR 2 in the same type of cells; ${ }^{\circ} \mathrm{p}<0.05$ compared with RyR2 or RyR3 in RPASMCs.

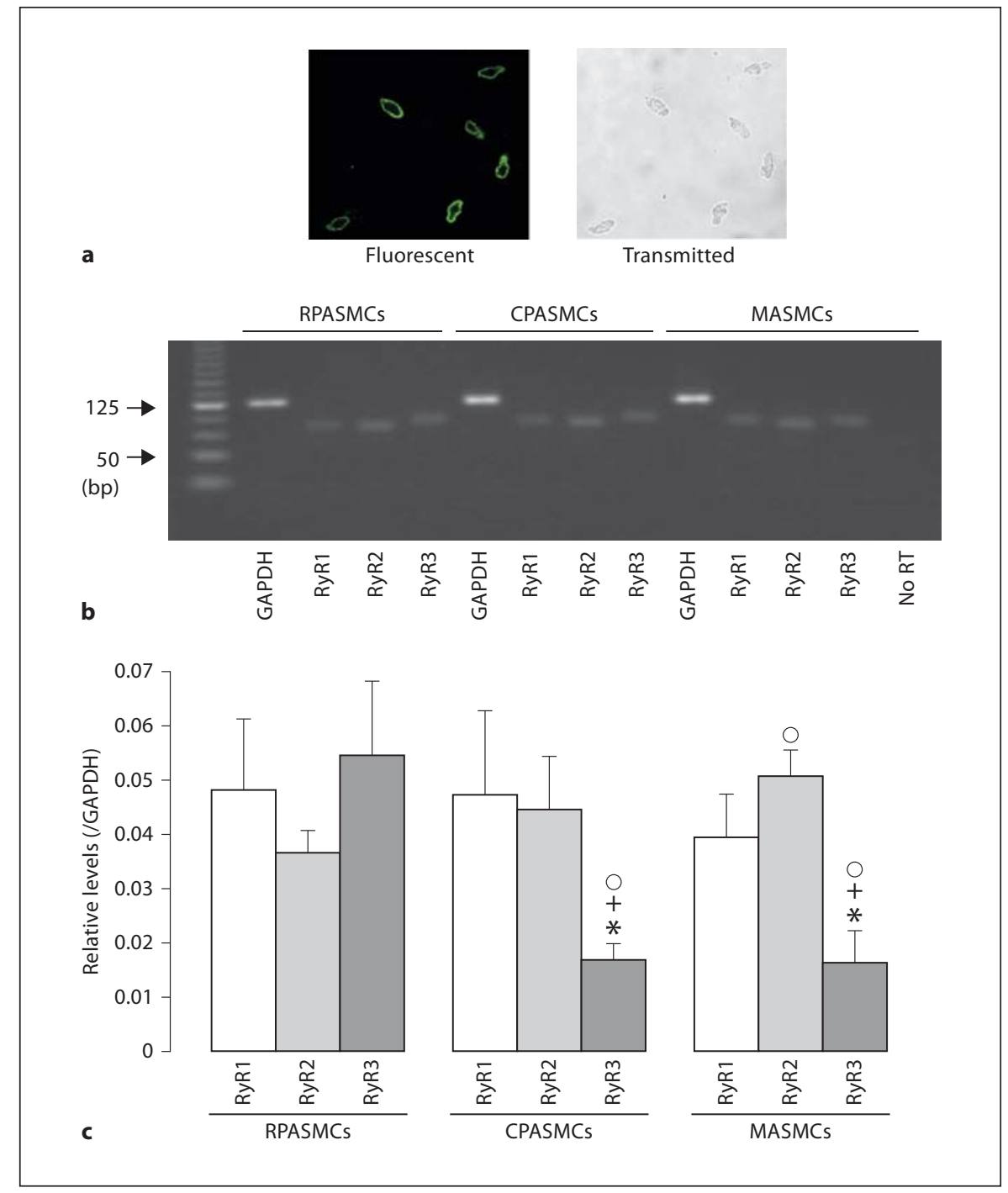

The mean increases in $\left[\mathrm{Ca}^{2+}\right]_{\mathrm{i}}$ were $519 \pm 76 \mathrm{nM}$ in RPASMCs $(\mathrm{n}=18), 459 \pm 53 \mathrm{nM}$ in CPASMCs $(\mathrm{n}=34)$ and $158 \pm 16 \mathrm{nM}$ in MASMCs $(\mathrm{n}=34$; fig. $4 \mathrm{~b})$. Moreover, $\mathrm{CMC}$ at a higher concentration $(3 \mathrm{mM})$ also induced a larger $\mathrm{Ca}^{2+}$ release in PASMCs than in MASMCs (fig. 4).

\section{High $\mathrm{K}^{+}$-Induced Increase in $\left[\mathrm{Ca}^{2+}\right]_{i}$}

It is well known that high extracellular $\mathrm{K}^{+}$can cause membrane depolarization and then activate VDCCs, resulting in the opening of RyRs and further $\mathrm{Ca}^{2+}$ release. Thus, we utilized high $\mathrm{K}^{+}$stimulation as an alternate approach to examine whether or not RyRs showed different functional activity in freshly isolated mouse RPASMCs, CPASMCs and MASMCs. High $\mathrm{K}^{+}$-induced responses are summarized in figure $5 \mathrm{~b}$, in which high $\mathrm{K}^{+}(50$ and
$100 \mathrm{mM}$ ) induced a larger increase in $\left[\mathrm{Ca}^{2+}\right]_{\mathrm{i}}$ in RPASMCs than in CPASMCs and MSAMCs.

\section{Hypoxia-Induced Increases in $\left[\mathrm{Ca}^{2+}\right]_{i}$}

Hypoxia induces a large, sustained vasoconstriction in pulmonary arteries, but not in systemic arteries. Moreover, hypoxic vasoconstriction is much greater in resistance than conduit pulmonary arteries [1-4]. These data, together with the fact that RyR-mediated $\mathrm{Ca}^{2+}$ release in SMCs plays a crucial role in the development of HPV [5, 7-10, 12, 33, 34], inspired us to examine and compare hypoxia-induced increases $\left[\mathrm{Ca}^{2+}\right]_{\mathrm{i}}$ in RPASMCs, CPASMCs and MASMCs. Typical examples of these experiments in RPASMCs and MASMCs are shown in figure $5 \mathrm{a}$. The mean increase in $\left[\mathrm{Ca}^{2+}\right]_{\mathrm{i}}$ following hypoxic challenge was 

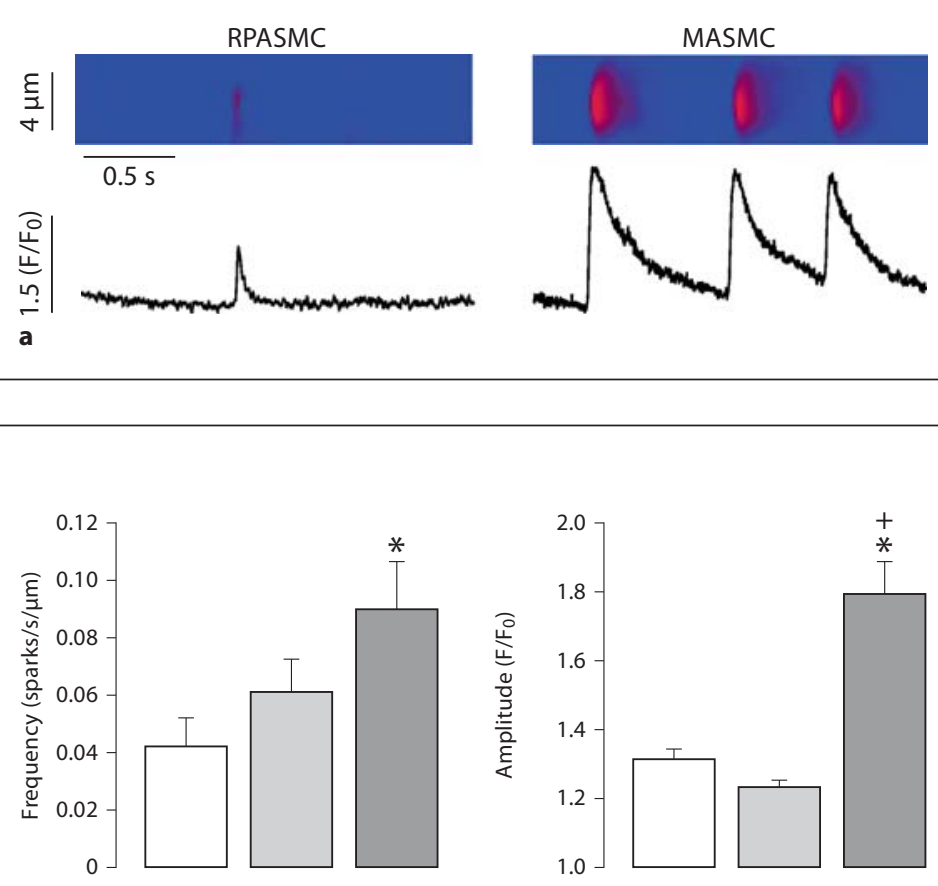

Fig. 2. Spatiotemporal characteristics of spontaneous $\mathrm{Ca}^{2+}$ sparks are different in mouse RPASMCs, CPASMCs and MASMCs. a Original line scan images show spontaneous $\mathrm{Ca}^{2+}$ sparks recorded in an RPASMC and MASMC. b Graphs summarize spatiotemporal characteristics of spontaneous $\mathrm{Ca}^{2+}$ sparks in RPASMCs (44 sparks, 31 cells), CPASMCs (84 sparks, 28 cells) and MASMCs (35 sparks, 12 cells). ${ }^{*} \mathrm{p}<0.05$ compared with RPASMCs; ${ }^{+} \mathrm{p}<$ 0.05 compared with CPASMCs.
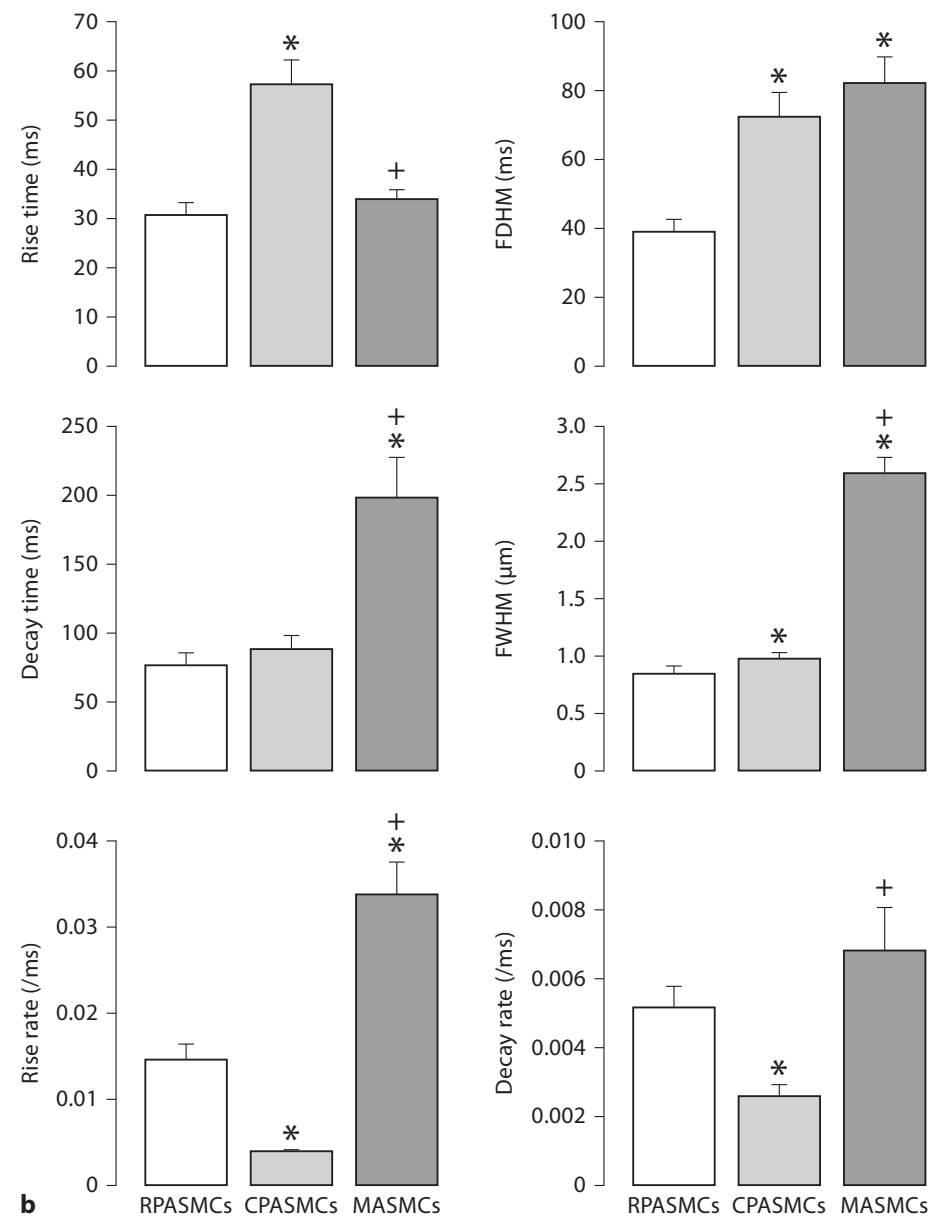


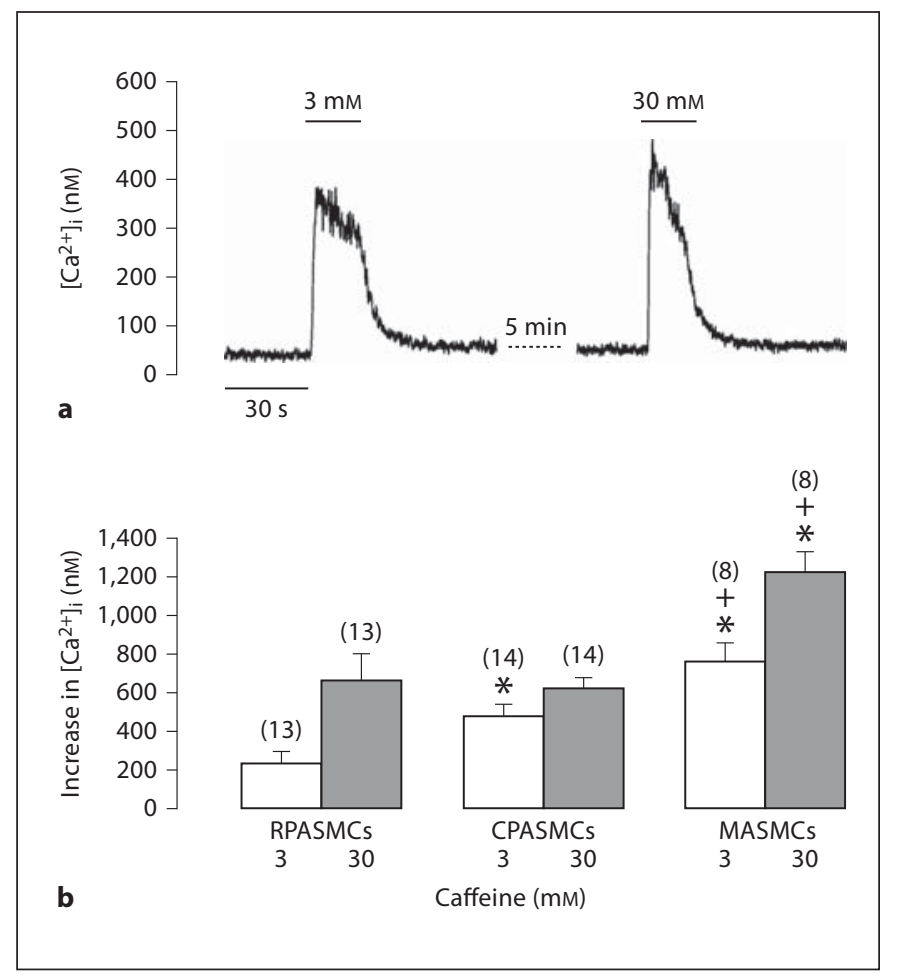

Fig. 3. Caffeine induces differential $\mathrm{Ca}^{2+}$ release in mouse resistance and conduit pulmonary as well as mesenteric artery myocytes. a Representative recordings show caffeine-induced increase in $\left[\mathrm{Ca}^{2+}\right]_{i}$ in an RPASMC. b Summary of caffeine-induced responses in RPASMCS, CPASMCs and MASMCs. Numbers in parentheses indicate the numbers of cells tested. ${ }^{*} \mathrm{p}<0.05 \mathrm{com}-$ pared with RPASMCs; ${ }^{+} \mathrm{p}<0.05$ compared with CPASMCs.
$315 \pm 17 \mathrm{nM}$ in RPASMCs $(\mathrm{n}=39), 96 \pm 11 \mathrm{nM}$ in CPASMCs $(\mathrm{n}=11)$ and $52 \pm 4 \mathrm{nM}$ in MASMCs $(\mathrm{n}=13$; fig. $6 b)$.

\section{Discussion}

In this study, we have found that RyR1, RyR2 and RyR3 mRNAs are expressed in freshly isolated mouse RPASMCs, CPASMCs and MASMCs using real-time quantitative RT-PCR (fig. 1). A couple of reports indicate that all $3 \mathrm{RyR} m \mathrm{~m} N A s$ are expressed in rat resistance pulmonary artery SMCs and tissues [12, 13]. Expression of RyR1, RyR2 and RyR3 mRNAs is often found in systemic vascular SMCs [14-16, 35], but previous studies have shown the presence of RyR2 and RyR3, but not RyR1 mRNAs in aortic tissues [17], and only RyR3 mRNA expression in cultured aortic SMCs [18]. These ambigu-

Ryanodine Receptors in Pulmonary and Systemic Artery Myocytes

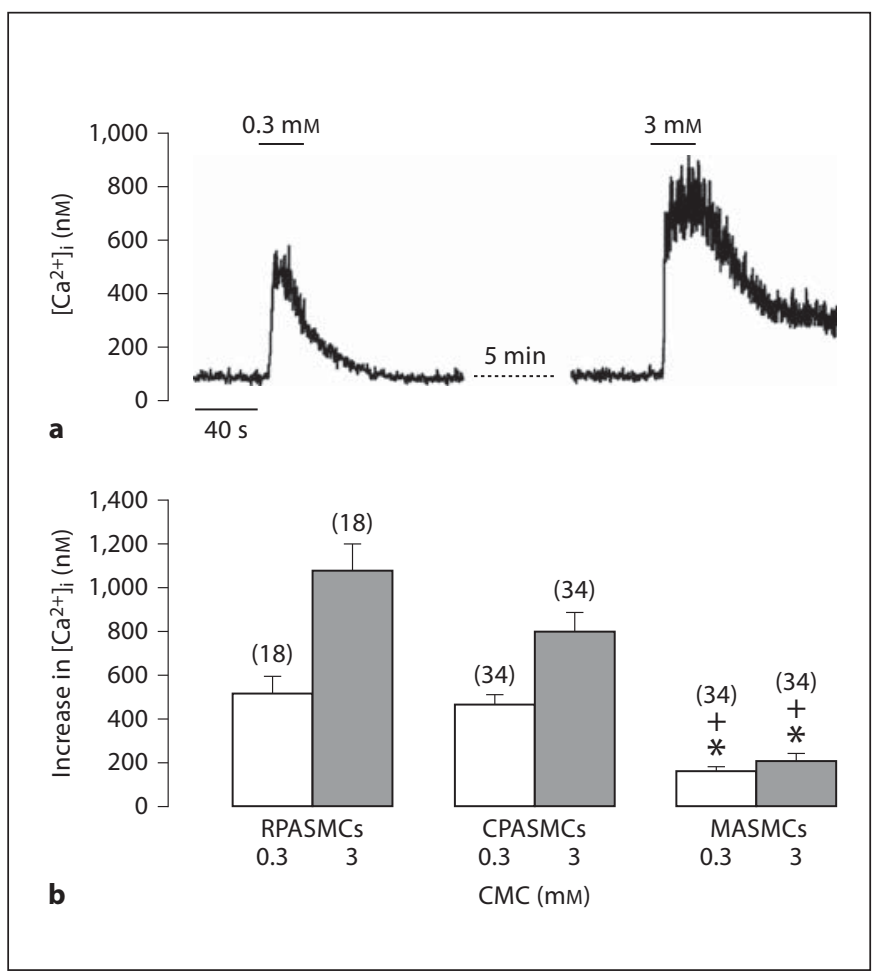

Fig. 4. $\mathrm{CMC}$ evokes heterogeneous $\mathrm{Ca}^{2+}$ release in mouse RPASMCs, CPASMCs and MASMCs. a Original recordings show CMC-induced $\mathrm{Ca}^{2+}$ release in an RPASMC. $\mathbf{b}$ Graph summarizes CMC-evoked increases in $\left[\mathrm{Ca}^{2+}\right]_{\mathrm{i}}$ in RPASMCs, CPASMCs and MASMCs. ${ }^{*} \mathrm{p}<0.05$ compared with RPASMCs; ${ }^{+} \mathrm{p}<0.05 \mathrm{com}-$ pared with CPASMCs.

ous data are likely to result from the potential contamination of endothelial and other cells in vascular tissues [26] or changes in RyR gene expression patterns and levels in cultured cells [18, 27, 28]. In support of this view, the RyR agonists caffeine and ryanodine are unable to induce $\mathrm{Ca}^{2+}$ release in cultured systemic (aortic) and pulmonary vascular SMCs $[12,18,27,28]$. The findings from this study using freshly isolated vascular SMCs extend these previous reports. Moreover, our data indicate that RyR1, RyR2 and RyR3 mRNA expression levels are significantly different between RPASMCs, CPASMCs and MASMCs. RyR1 expression level is similar in all 3 vascular SMCs, RyR2 level is RPASMCs $\approx$ CPASMCs $<$ MASMCs and RyR3 level is RPASMCs $>$ CPASMCs $\approx$ MASMCs. It may be interesting to perform additional studies in the future to determine the functional consequences of the differential expression patterns and levels of RyR1, RyR2 and RyR3 genes in RPASMCS, CPASMCs and MASMCs. 


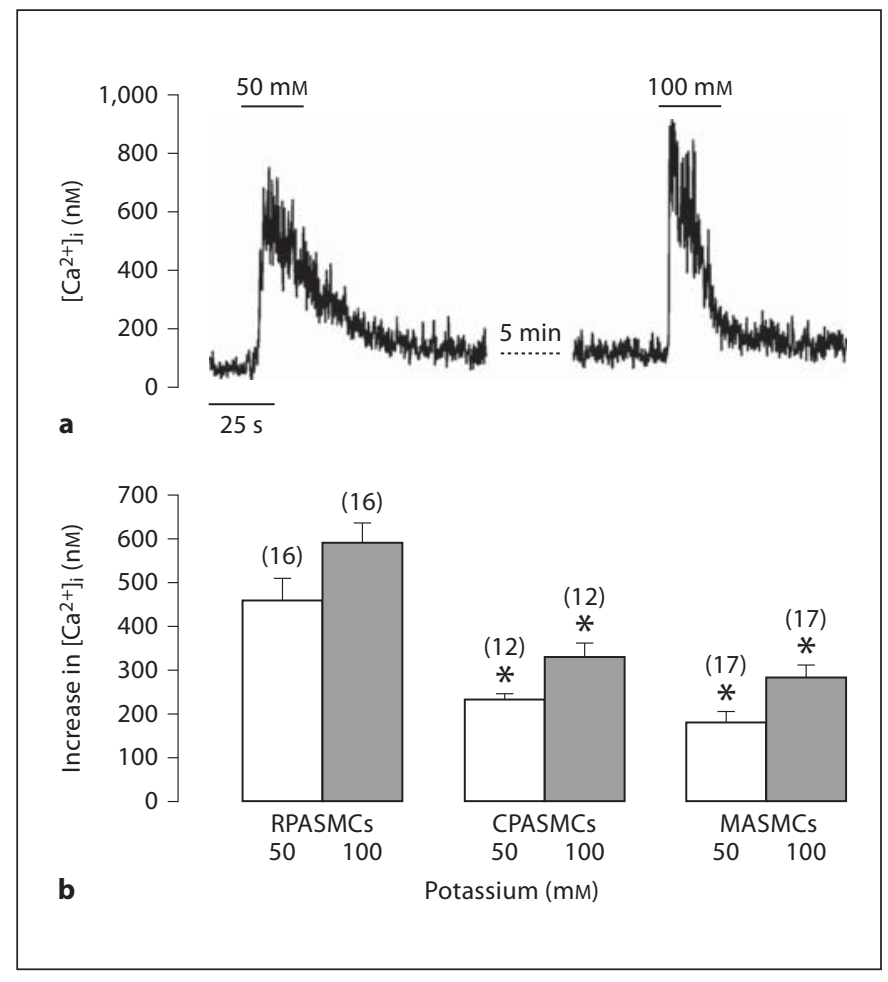

Fig. 5. High $\mathrm{K}^{+}$evokes heterogeneous increases in $\left[\mathrm{Ca}^{2+}\right]_{\mathrm{i}}$ in mouse resistance and conduit pulmonary as well as mesenteric artery myocytes. a Recording traces show high $\mathrm{K}^{+}$-induced increase in $\left[\mathrm{Ca}^{2+}\right]_{\mathrm{i}}$ in an RPASMC. b Summary of high $\mathrm{K}^{+}$-induced responses in RPASMCs, CPASMCs and MASMCs. ${ }^{*} \mathrm{p}<0.05$ compared with RPASMCs.

By means of a laser scanning confocal microscope (Zeiss LSM510), we have observed spontaneous $\mathrm{Ca}^{2+}$ sparks (functional events of RyRs) in freshly isolated mouse RPASMCs, CPASMCs and MASMCs (fig. 2). The spatiotemporal characteristics of $\mathrm{Ca}^{2+}$ sparks, however, differ in these 3 types of cells. In general, $\mathrm{Ca}^{2+}$ sparks show a lower frequency, slower rise rate, lower amplitude, shorter duration and smaller size in RPASMCs than in MASMCs, whereas $\mathrm{Ca}^{2+}$ sparks in CPASMCs show mixed characteristics of RPASMCs and MASMCs. It is known that native RyR1 in skeletal myocytes generates $\mathrm{Ca}^{2+}$ sparks at a lower frequency [36], while native RyR2 in cardiac cells produces $\mathrm{Ca}^{2+}$ sparks at a higher frequency [37]. The role of native RyR3 in the generation of $\mathrm{Ca}^{2+}$ sparks in muscle cells is unclear, but previous studies have shown that RyR3 gene deletion has no effect on the activity of $\mathrm{Ca}^{2+}$ sparks in mouse bladder and cerebral artery SMCs $[16,38]$. Presumably, the differential activity of $\mathrm{Ca}^{2+}$ sparks between the vascular SMCs (RPASMCs $<$

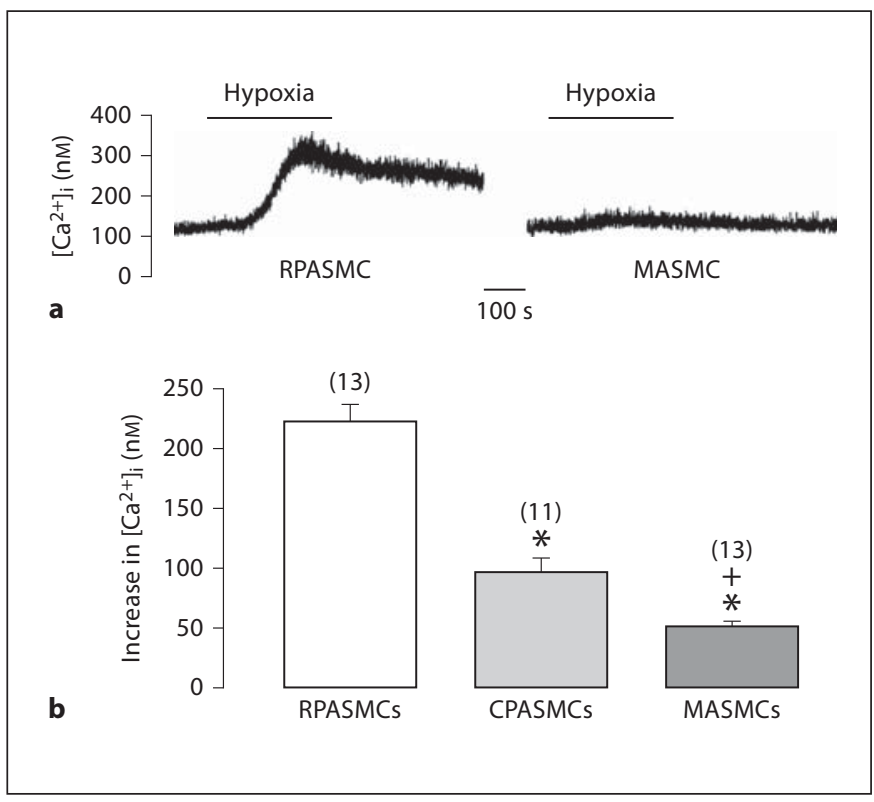

Fig. 6. Hypoxia-induced increases in $\left[\mathrm{Ca}^{2+}\right]_{\mathrm{i}}$ are different in mouse RPASMCs, CPASMCs and MASMCs. a Representative traces show hypoxia-induced increase in $\left[\mathrm{Ca}^{2+}\right]_{\mathrm{i}}$ in an RPASMC and MASMC. b Graph summarizes hypoxic $\mathrm{Ca}^{2+}$ responses in RPASMCs, CPASMCs and MASMCs. * $\mathrm{p}<0.05$ compared with RPASMCs; ${ }^{+} \mathrm{p}<0.05$ compared with CPASMCs.

MASMCs) is possibly due to diversities in functional expression and/or activity (per se) of RyR2, RyR1 or both. It is generally believed that the number of RyRs in the cluster to form a functional $\mathrm{Ca}^{2+}$ release unit determines the $\mathrm{Ca}^{2+}$ spark amplitude, and may also affect $\mathrm{Ca}^{2+}$ spark duration and spread size. This, together with the failure of RyR3 gene deletion to affect $\mathrm{Ca}^{2+}$ sparks in vascular and other SMCs [16, 38], leads us to speculate that smaller amplitude, shorter duration and smaller size of $\mathrm{Ca}^{2+}$ sparks in PASMCs relative to MASMCs are likely attributed, in part, to the lower number of functional RyR2 and/or RyR1 in the former cells than in the latter.

Caffeine, a prototypical agonist of RyRs, induces heterogeneous $\mathrm{Ca}^{2+}$ release in RPASMCs, CPASMCs and MASMCs (fig. 3). Similarly, the RyR agonist CMC also triggers differential $\mathrm{Ca}^{2+}$ release in these 3 vascular SMCs (fig. 4). Moreover, high $\mathrm{K}^{+}$exposure to open RyRs by activating VDCCs produces a larger increase in $\left[\mathrm{Ca}^{2+}\right]_{\mathrm{i}}$ in RPASMCs than in CPASMCs and MASMCs (fig. 5). Taken together, these results further indicate that the functional expression or activity of RyRs is dissimilar in 3 vascular cells. Intriguingly, we have also found that caffeine-induced $\mathrm{Ca}^{2+}$ release is correlated positively with 
RyR2 gene expression, but negatively with RyR3 gene expression in PASMCs and MASMCs; furthermore, there is greater CMC-induced increase in $\left[\mathrm{Ca}^{2+}\right]_{i}$ as well as higher RyR3 and lower RyR2 expression in PASMCs than in MASMCs. Although the biological significance of these phenomena is unclear, previous studies have shown that the sensitivity to caffeine is RyR2 $>$ RyR1 [39] and RyR3 > RyR1 [40]; CMC has a lower sensitivity in RyR3 than in RyR1 and RyR2 [40, 41]. Thus, we presume that the divergence in caffeine-induced $\mathrm{Ca}^{2+}$ release in PASMCs and MASMCs is likely to be associated with the differential expression and/or activity of RyR2, whereas the different CMC response is possibly related to the dissimilar expression and/or activity of RyR3.

Numerous studies suggest that RyR-mediated $\mathrm{Ca}^{2+} \mathrm{re}-$ lease is a key factor for hypoxia-induced increase in $\left[\mathrm{Ca}^{2+}\right]_{\mathrm{i}}$ and associated contraction in PASMCs $[5,7-11$, 33, 34]. Our recent work reveals that RyR3 gene deletion selectively inhibits hypoxia-induced increase in $\left[\mathrm{Ca}^{2+}\right]_{i}$ and contraction in mouse RPASMCs [12]. In this study, we have found that RyR3 mRNA expression level is much higher in PASMCs than in MASMCs (fig. 1). More importantly, hypoxia induces a large increase in $\left[\mathrm{Ca}^{2+}\right]_{\mathrm{i}}$ in PASMCs, but not in MASMCs (fig. 6). Collectively, the observed differences in hypoxia-induced $\mathrm{Ca}^{2+}$ release and associated vasoconstriction in PASMCs and MASMCs may perhaps be associated with the heterogeneity of functional RyR3 expression, activity or both. While further experiments in the future are necessary to confirm this notion, the importance of RyR3 and also possibly other RyR subtypes in hypoxic $\mathrm{Ca}^{2+}$ and contractile responses in PASMCs is reinforced by the findings that hypoxic $\mathrm{Ca}^{2+}$ release through RyRs may result in the opening of store-operated $\mathrm{Ca}^{2+}$ channels, which causes not only $\mathrm{Ca}^{2+}$ influx through the opening channels, but also membrane depolarization and $\mathrm{Ca}^{2+}$ influx via VDCCs, providing a positive feedback mechanism to enhance hypoxic increase in $\left[\mathrm{Ca}^{2+}\right]_{\mathrm{i}}$ and contraction $[42$, 43]. In support of these findings, an elegant study using a genetic approach has demonstrated that acute HPV is completely abolished in isolated lungs from canonical transient receptor potential 6 (an important member of store-operated $\mathrm{Ca}^{2+}$ channels) gene-deleted mice [44].

Considering that hypoxia can cause $\mathrm{K}_{\mathrm{V}}$ channel inhibition and membrane depolarization in PASMCs [22, 23], several research groups have started to examine the role of $\mathrm{K}_{\mathrm{V}}$ channels in the heterogeneity of hypoxic $\mathrm{Ca}^{2+}$ and contractile responses in RPASMCs, CPASMCs and systemic artery SMCs. Yuan et al. [23] have shown that hypoxia inhibits $\mathrm{K}_{\mathrm{V}}$ currents in PASMCs, but not in
MASMCs. Additionally, hypoxic inhibition of $\mathrm{K}_{\mathrm{V}}$ currents is greater in RPASMCs than CPASMCs [1]. However, studies aimed at looking into the molecular identity of hypoxia-responsible $\mathrm{K}_{\mathrm{V}}$ channels have yielded largely inconsistent results $[45,46]$. It should also be noted that hypoxic increases in $\left[\mathrm{Ca}^{2+}\right]_{i}$ and contraction in PASMCs are well preserved in the presence of $\mathrm{K}_{\mathrm{V}}$ channel blockers and high extracellular $\mathrm{K}^{+}$[47-50], and $\mathrm{Ca}^{2+}$ release from the sarcoplasmic reticulum may mediate the hypoxic inhibition of $K_{V}$ channels in PASMCs [51-53]. Nevertheless, it is worthy for additional experiments to verify the causal relationship between $\mathrm{K}_{\mathrm{V}}$ channels and the diversity of hypoxic responses in PASMCs and systemic artery SMCs.

A well-designed study by Leach et al. [54] has shown that hypoxia results in an initial transient and a subsequent sustained contraction in pulmonary arteries in the presence of intact endothelium, but only triggers an initial transient contraction without a second contraction following mechanical removal of endothelium; however, the hypoxic response is absent in mesenteric arteries, and only manifests an initial phase following prostaglandin F2 $\alpha$-induced pretone. These intriguing data raise another possibility that factors released from the endothelium may affect the contractility in SMCs, playing a role in the heterogeneity of hypoxic responses in pulmonary and systemic circulation. It should also be noted that the importance of inositol 1,4,5-triphosphate receptors ( $\left.\mathrm{IP}_{3} \mathrm{Rs}\right)$ is well established in vascular SMCs, but its role in hypoxia-induced responses is unclear. It has been proposed that a significant increase in $\left[\mathrm{Ca}^{2+}\right]_{\mathrm{i}}$ may result in the activation of $\mathrm{IP}_{3} \mathrm{Rs}$ and consequent $\mathrm{Ca}^{2+}$ release at a resting $\mathrm{IP}_{3}$ level [55]. Thus, it is probable that during hypoxic stimulation, $\mathrm{Ca}^{2+}$ release through RyRs could open adjacent $\mathrm{IP}_{3} \mathrm{Rs}$ and subsequently induce further $\mathrm{Ca}^{2+}$ release in PASMCs; as such, this local CICR would contribute to hypoxic increase in $\left[\mathrm{Ca}^{2+}\right]_{i}$. Because hypoxia causes, at best, a minimal increase in $\left[\mathrm{Ca}^{2+}\right]_{\mathrm{i}}$ in systemic (mesenteric) vascular SMCs, we assume that the CICR process mediated by the local RyR/IP ${ }_{3} \mathrm{R}$ interaction might not happen in this cell type.

\section{Conclusion}

In the present study, we demonstrate that RyR1, RyR2 and RyR 3 mRNAs are expressed in freshly isolated mouse RPASMCs, CPASMCs and MASMCs, and their expression levels are different. Our functional studies reveal that the spontaneous opening probability of RyRs, as well 
as agonist- and hypoxia-induced, RyR-mediated $\mathrm{Ca}^{2+} \mathrm{re}-$ lease are also different in these 3 types of vascular SMCs. Therefore, RyRs are heterogeneous in gene expression and functional activity in RPSMCs, CPASMCs and MASMCs, which may contribute to the divergence in excitation-contraction coupling and hypoxia-induced responses in these 3 vascular SMCs. There is a fair amount of evidence that RyR1, RyR2 and RyR3 show distinct roles in the generation of $\mathrm{Ca}^{2+}$ sparks and produce different responses to caffeine and $\mathrm{CMC}$; as such, we contemplate that the observed diversity in $\mathrm{Ca}^{2+}$ spark spatiotemporal characteristics as well as agonist- and hypoxia-induced $\mathrm{Ca}^{2+}$ responses in different vascular SMCs may perhaps be related to the dissimilar expression and/or function of 3 RyR subtypes.

\section{Acknowledgements}

The authors are grateful to Ms. Jodi Heim for her technical assistance. This work was supported by the American Heart Association and the National Institutes of Health (Y.-X.W.).

\section{References}

$\checkmark 1$ Archer SL, Huang JM, Reeve HL, et al: Differential distribution of electrophysiologically distinct myocytes in conduit and resistance arteries determines their response to nitric oxide and hypoxia. Circ Res 1996;78: 431-442.

$\checkmark 2$ Madden JA, Dawson CA, Harder DR: Hypoxia-induced activation in small isolated pulmonary arteries from the cat. J Appl Physiol 1985;59:113-118

3 Madden JA, Vadula MS, Kurup VP: Effects of hypoxia and other vasoactive agents on pulmonary and cerebral artery smooth muscle cells. Am J Physiol 1992;263:L384-L393.

$\checkmark 4$ Bennie RE, Packer CS, Powell DR, Jin N, Rhoades RA: Biphasic contractile response of pulmonary artery to hypoxia. Am J Physiol 1991;261:L156-L163.

5 Wang YX, Zheng YM, Abdullaev II, Kotlikoff MI: Metabolic inhibition with cyanide induces intracellular calcium release in pulmonary artery myocytes and Xenopus oocytes. Am J Physiol Cell Physiol 2003;284 C378-C388.

6 Rathore R, Zheng YM, Li XQ, et al: Mitochondrial ROS-PKC $\varepsilon$ signaling axis is uniquely involved in hypoxic increase in $\left[\mathrm{Ca}^{2+}\right]_{\mathrm{i}}$ in pulmonary artery smooth muscle cells. Biochem Biophys Res Commun 2006; 351:784-790.

7 Vadula MS, Kleinman JG, Madden JA: Effect of hypoxia and norepinephrine on cytoplasmic free $\mathrm{Ca}^{2+}$ in pulmonary and cerebral arterial myocytes. Am J Physiol 1993;265: L591-L597.

$>8$ Jabr RI, Toland H, Gelband $\mathrm{CH}$, Wang XX, Hume JR: Prominent role of intracellular $\mathrm{Ca}^{2+}$ release in hypoxic vasoconstriction of canine pulmonary artery. Br J Pharmacol 1997;122:21-30.

$\checkmark 9$ Dipp M, Nye PC, Evans AM: Hypoxic release of calcium from the sarcoplasmic reticulum of pulmonary artery smooth muscle. Am J Physiol Lung Cell Mol Physiol 2001;281: L318-L325.
Salvaterra CG, Goldman WF: Acute hypoxia increases cytosolic calcium in cultured pulmonary arterial myocytes. Am J Physiol 1993;264:L323-L328.

11 Zheng YM, Mei QB, Wang QS, et al: Role of FKBP12.6 in hypoxia- and norepinephrineinduced $\mathrm{Ca}^{2+}$ release and contraction in pulmonary artery myocytes. Cell Calcium 2004; 35:345-355.

12 Zheng YM, Wang QS, Rathore R, et al: Type3 ryanodine receptors mediate hypoxia-, but not neurotransmitter-induced calcium release and contraction in pulmonary artery smooth muscle cells. J Gen Physiol 2005;125: 427-440.

13 Yang XR, Lin MJ, Yip KP, et al: Multiple ryanodine receptor subtypes and heterogeneous ryanodine receptor-gated $\mathrm{Ca}^{2+}$ stores in pulmonary arterial smooth muscle cells. Am J Physiol Lung Cell Mol Physiol 2005; 289:L338-L348.

14 Neylon CB, Richards SM, Larsen MA, Agrotis A, Bobik A: Multiple types of ryanodine receptor/Ca ${ }^{2+}$ release channels are expressed in vascular smooth muscle. Biochem Biophys Res Commun 1995;215:814-821.

15 Coussin F, Macrez N, Morel JL, Mironneau $\mathrm{J}$ : Requirement of ryanodine receptor subtypes 1 and 2 for $\mathrm{Ca}^{2+}$-induced $\mathrm{Ca}^{2+}$ release in vascular myocytes. J Biol Chem 2000;275: 9596-9603.

16 Lohn M, Jessner W, Furstenau M, et al: Regulation of calcium sparks and spontaneous transient outward currents by RyR 3 in arterial vascular smooth muscle cells. Circ Res 2001;89:1051-1057.

17 Ledbetter MW, Preiner JK, Louis CF, Mickelson JR: Tissue distribution of ryanodine receptor isoforms and alleles determined by reverse transcription polymerase chain reaction. J Biol Chem 1994;269:31544-31551.

18 Vallot O, Combettes L, Jourdon P, et al: Intracellular $\mathrm{Ca}^{2+}$ handling in vascular smooth muscle cells is affected by proliferation. Arterioscler Thromb Vasc Biol 2000;20:12251235.
9 Fill M, Copello JA: Ryanodine receptor calcium release channels. Physiol Rev 2002;82: 893-922.

20 Zima AV, Copello JA, Blatter LA: Differential modulation of cardiac and skeletal muscle ryanodine receptors by NADH. FEBS Lett 2003;547:32-36.

21 Yamaguchi N, Xu L, Pasek DA, Evans KE, Chen SR, Meissner G: Calmodulin regulation and identification of calmodulin binding region of type-3 ryanodine receptor calcium release channel. Biochemistry 2005;44: 15074-15081.

22 Post JM, Hume JR, Archer SL, Weir EK: Direct role for potassium channel inhibition in hypoxic pulmonary vasoconstriction. Am J Physiol 1992;262:C882-C890.

23 Yuan XJ, Goldman WF, Tod ML, Rubin LJ, Blaustein MP: Hypoxia reduces potassium currents in cultured rat pulmonary but not mesenteric arterial myocytes. Am J Physiol 1993;264:L116-L123.

24 Michelakis ED, Hampl V, Nsair A, et al: Diversity in mitochondrial function explains differences in vascular oxygen sensing. Circ Res 2002;90:1307-1315.

25 Wang QS, Zheng YM, Dong L, Ho YS, Guo $\mathrm{Z}$, Wang YX: Role of mitochondrial reactive oxygen species in hypoxia-dependent increase in intracellular calcium in pulmonary artery myocytes. Free Radic Biol Med 2007; 42:642-653.

26 Knot HJ: Calcium sparks unleashed in vascular smooth muscle: lessons from the RyR3 knockout mouse. Circ Res 2001;89:941-943.

27 Masuo M, Toyo-oka T, Shin WS, Sugimoto T: Growth-dependent alterations of intracellular $\mathrm{Ca}^{2+}$-handling mechanisms of vascular smooth muscle cells: PDGF negatively regulates functional expression of voltage-dependent, $\mathrm{IP}_{3}$-mediated, and $\mathrm{Ca}^{2+}$-induced $\mathrm{Ca}^{2+}$ release channels. Circ Res 1991;69: 1327-1339.

28 Cortes SF, Lemos VS, Stoclet JC: Alterations in calcium stores in aortic myocytes from spontaneously hypertensive rats. Hypertension 1997;29:1322-1328. 
-29 Liu QH, Zheng YM, Wang YX: Two distinct signaling pathways for regulation of spontaneous local $\mathrm{Ca}^{2+}$ release by phospholipase $\mathrm{C}$ in airway smooth muscle cells. Pflugers Arch 2007;453:531-541.

-30 Bolton TB, Gordienko DV: Confocal imaging of calcium release events in single smooth muscle cells. Acta Physiol Scand 1998;164: 567-575.

-31 Janiak R, Wilson SM, Montague S, Hume JR: Heterogeneity of calcium stores and elementary release events in canine pulmonary arterial smooth muscle cells. Am J Physiol Cell Physiol 2001;280:C22-C33.

-32 Remillard CV, Zhang WM, Shimoda LA, Sham JS: Physiological properties and functions of $\mathrm{Ca}^{2+}$ sparks in rat intrapulmonary arterial smooth muscle cells. Am J Physiol Lung Cell Mol Physiol 2002;283:L433L444.

33 Wilson HL, Dipp M, Thomas JM, Lad C, Galione A, Evans AM: ADP-ribosyl cyclase and cyclic ADP-ribose hydrolase act as a redox sensor. a primary role for cyclic ADP-ribose in hypoxic pulmonary vasoconstriction. J Biol Chem 2001;276:11180-11188.

-34 Dipp M, Evans AM: Cyclic ADP-ribose is the primary triggered for hypoxic pulmonary vasoconstriction in the rat lung in situ. Circ Res 2001;89:77-83.

- 35 Mironneau J, Coussin F, Jeyakumar LH, Fleischer S, Mironneau C, Macrez N: Contribution of ryanodine receptor subtype 3 to $\mathrm{Ca}^{2+}$ responses in $\mathrm{Ca}^{2+}$-overloaded cultured rat portal vein myocytes. J Biol Chem 2001; 276:11257-11264.

-36 Schneider MF, Ward CW: Initiation and termination of calcium sparks in skeletal muscle. Front Biosci 2002;7:d1212-d1222.

-37 Cheng H, Lederer WJ, Cannell MB: Calcium sparks: elementary events underlying excitation-contraction coupling in heart muscle. Science 1993;262:740-744.
38 Ji G, Feldman ME, Greene KS, Sorrentino V, Xin HB, Kotlikoff MI: RYR2 proteins contribute to the formation of $\mathrm{Ca}^{2+}$ sparks in smooth muscle. J Gen Physiol 2004;123:377386.

39 Copello JA, Barg S, Sonnleitner A, et al: Differential activation by $\mathrm{Ca}^{2+}$, ATP and caffeine of cardiac and skeletal muscle ryanodine receptors after block by $\mathrm{Mg}^{2+}$. J Membr Biol 2002; 187:51-64.

40 Fessenden JD, Wang Y, Moore RA, Chen SR, Allen PD, Pessah IN: Divergent functional properties of ryanodine receptor types 1 and 3 expressed in a myogenic cell line. Biophys J 2000;79:2509-2525.

41 Fessenden JD, Perez CF, Goth S, Pessah IN, Allen PD: Identification of a key determinant of ryanodine receptor type 1 required for activation by 4-chloro-m-cresol. J Biol Chem 2003;278:28727-28735.

42 Ng LC, Wilson SM, Hume JR: Mobilization of sarcoplasmic reticulum stores by hypoxia leads to consequent activation of capacitative $\mathrm{Ca}^{2+}$ entry in isolated canine pulmonary arterial smooth muscle cells. J Physiol 2005; 563:409-419.

43 Ng LC, Wilson SM, McAllister CE, Hume JR: Role of $\mathrm{InsP}_{3}$ and ryanodine receptors in the activation of capacitative $\mathrm{Ca}^{2+}$ entry by store depletion or hypoxia in canine pulmonary arterial smooth muscle cells. Br J Pharmacol 2007;152:101-111.

44 Weissmann N, Dietrich A, Fuchs B, et al: Classical transient receptor potential channel 6 (TRPC6) is essential for hypoxic pulmonary vasoconstriction and alveolar gas exchange. Proc Natl Acad Sci USA 2006;103: 19093-19098.

45 Sylvester JT: Hypoxic pulmonary vasoconstriction: a radical view. Circ Res 2001;88: 1228-1230.
46 Sham JS: Hypoxic pulmonary vasoconstriction: ups and downs of reactive oxygen species. Circ Res 2002;91:649-651.

47 Hasunuma K, Rodman DM, McMurtry IF: Effects of $\mathrm{K}^{+}$channel blockers on vascular tone in the perfused rat lung. Am Rev Respir Dis 1991; 144:884-887.

48 Sham JS, Crenshaw BR, Jr., Deng LH, Shimoda LA, Sylvester JT: Effects of hypoxia in porcine pulmonary arterial myocytes: roles of $\mathrm{K}_{\mathrm{V}}$ channel and endothelin-1. Am J Physiol Lung Cell Mol Physiol 2000;279:L262L272.

49 Robertson TP, Hague D, Aaronson PI, Ward JP: Voltage-independent calcium entry in hypoxic pulmonary vasoconstriction of intrapulmonary arteries of the rat. J Physiol 2000;525:669-680.

50 Kang TM, Park MK, Uhm DY: Characterization of hypoxia-induced $\left[\mathrm{Ca}^{2+}\right]_{i}$ rise in rabbit pulmonary arterial smooth muscle cells. Life Sci 2002;70:2321-2333.

51 Gelband $\mathrm{CH}$, Gelband $\mathrm{H}: \mathrm{Ca}^{2+}$ release from intracellular stores is an initial step in hypoxic pulmonary vasoconstriction of rat pulmonary artery resistance vessels. Circulation 1997;96:3647-3654.

52 Vandier C, Delpech M, Bonnet P: Spontaneous transient outward currents and delayed rectifier $\mathrm{K}^{+}$current: effects of hypoxia. Am J Physiol 1998;275(1 Pt 1):L145-L154.

-53 Post JM, Gelband CH, Hume JR: $\left[\mathrm{Ca}^{2+}\right]_{\mathrm{i}}$ inhibition of $\mathrm{K}^{+}$channels in canine pulmonary artery: novel mechanism for hypoxia-induced membrane depolarization. Circ Res 1995;77:131-139.

54 Leach RM, Robertson TP, Twort CH, Ward JP: Hypoxic vasoconstriction in rat pulmonary and mesenteric arteries. Am J Physiol 1994;266:L223-L231.

55 Ehrlich BE, Kaftan E, Bezprozvannaya S, Bezprozvanny I: The pharmacology of intracellular $\mathrm{Ca}^{2+}$-release channels. Trends Pharmacol Sci 1994;15:145-149. 